\title{
PENERAPAN EUCLIDEAN PROBABILITY DALAM MENDIAGNOSIS ATOPIK DERMATIS
}

\author{
Puji Sari Ramadhan*1 \\ ${ }^{1}$ Sistem Informasi, STMIK Triguna Dharma \\ Email: ${ }^{1}$ pujisariramadhan@gmail.com \\ *Penulis Korespondensi
}

(Naskah masuk: 16 Mei 2019, diterima untuk diterbitkan: 05 Oktober 2020)

\begin{abstract}
Abstrak
Atopik Dermatis atau yang lebih dikenal dengan istilah Eksim Susu merupakan penyakit yang terjadi pada anak pada bagian kulit. Tingginya penyebaran penyakit ini terhadap bayi atau anak-anak, maka perlu melakukan antisipasi dengan cara membangun sebuah sistem yang mampu menghasilkan pengetahuan dan informasi tentang Atopik Dermatis, sehingga dapat mengurangi resiko penyebaran penyakit ini serta dapat sesegera mungkin untuk dapat dilakukan penanganan dini terhadap penderita. Sistem yang akan dibentuk adalah dengan cara memindahkan segala bentuk informasi dan pengetahuan tentang Atopik Dermatis ke dalam aplikasi diagnosis dengan menerapkan keilmuan Sistem Pakar yang menggunakan analisa Euclidean Probability. Penggunaan metode ini dalam melakukan diagnosis nantinya dapat memberikan kontribusi dalam pengembangan dan kebaruan dalam penggunaan metode pada keilmuan sistem pakar dalam menghasilkan kesimpulan diagnosis. Selain itu dengan penerapan metode ini kedalam aplikasi diagnosis dapat membantu masyarakat luas dalam melakukan diagnosis tentang Atopik Dermatis, hal ini didasari dengan banyaknya penggunaan metode ini dalam penelitian sebelumnya, serta terlihat dari hasil pengujian yang telah dilakukan maka dapat diketahui bahwa Euclidean Probability menghasilkan nilai akurasi $100 \%$ dari data yang tervalidasi dan hasil diagnosis Euclidean Probability lebih optimal dibanding dengan teknik konvensional serta metode sistem pakar lainnya.
\end{abstract}

Kata kunci: Sistem Pakar, Euclidean Probability, Atopik Dermatis

\section{IMPLEMENTATION OF EUCLIDEAN PROBABILITY IN DERMATIC ATOPIC DIAGNOSIS}

\begin{abstract}
Atopic Dermatitis, better known as Milk Eczema, is a disease that occurs in children on the skin. The high spread of this disease to infants or children, it is necessary to anticipate by building a system that can produce knowledge and information about Atopic Dermatitis, to reduce the risk of spreading this disease and early treatment for sufferers as soon as possible. The system that will be formed is by transferring all forms of information and knowledge about Atopic Dermatitis into the diagnosis application using Euclidean Probability analysis. The use of this method in making a diagnosis later can contribute to the development and novelty of the use of techniques in scientific expert systems in generating diagnosis conclusions. Also, by applying this method into the application of diagnosis can help the broader community in making a diagnosis of Atopic Dermatitis. This is based on the many uses of this method in previous studies, and it can be seen from the results of testing that Euclidean Probability produces an accuracy value of $100 \%$ of validated data and the effects of Euclidean diagnosis Probability is more optimal compared to conventional techniques and other expert system methods.
\end{abstract}

Keywords: Expert system, Euclidean Probability, Atopic Dermatic

\section{PENDAHULUAN}

Seperti diketahui bahwa kondisi setiap bayi atau anak berbeda-beda dalam sistem pertahanan tubuh dalam melawan serangan dari luar, hal inilah yang menyebabkan bayi atau anak-anak dapat terserang penyakit jika memiliki kondisi pertahanan tubuh yang lemah, selain itu faktor genetik atau keturunan juga dapat mempengaruhi kondisi sistem kekebalan tubuh pada anak. Salah satu penyakit yang menyerang bayi atau anak adalah Atopik Dermatis, yang merupakan jenis penyakit yang sering terjadi pada bagian kulit anak-anak, penyakit 
ini dapat mengakibatkan kelembaban kuit pada anak akan hilang atau berkurang dan cenderung kering, sehingga akan rentan terhadap serangan keadaan luar tubuh yaitu debu, kuman, dan virus hal ini disebabkan keadaan lingkungan seperti faktor debu, kuman, dan virus. Selain dari faktor tersebut penyakit ini juga dipengaruhi oleh genetik, imonologik dan farmakologik sehingga anak yang menderita Atopik Dermatis dapat terkena peradangan kronis kulit residif.

Atopik Dermatis adalah jenis penyakit eksim yang sering disebut eksim susu yang pada umumnya sering menyerang bayi atau anak dengan usia dini yang dijelaskan pada(Akib, A. Roma, 2015). Selain itu pendapat lain mengemukakan bahwa Atopik Dermatis menyerang sel IgE dan kecenderungan penderita akan mengalami reaksi kulit seperti rhinitis, rasa gatal, kulit bersisik, bagian kulit pecahpecah, demam, panas pada bagian kulit dan peradangan kulit dalam(Maharani, 2015)

Setiap bayi atau anak tentunya memiliki kemungkinan terjangkit penyakit ini, maka hal tersebut perlu diantisipasi dengan cara membangun sebuah sistem yang mampu memberikan pengetahuan dan informasi yang berkaitan dengan Atopik Dermatis, sehingga nantinya masyarakat dapat mengetahui tentang diagnosis Atopik Dermatis yang tentunya dapat mempercepat penanganan dini terhadap anak atau bayi yang terkena Atopik Dermatis. Sistem yang sesuai dengan penyelesaian permasalahan diagnosis diatas adalah dengan menerapkan konsep Sistem Pakar yang telah teruji dan sering digunakan dalam menyelesaikan permasalahan yang berkaitan dengan kehidupan sehari-hari.

Dalam penelitian sebelumnya mengemukakan bahwa Sistem Pakar didefinisikan sebagai program yang berfungsi untuk menemukan solusi atas permasalahan yang dialami(Minarn, Warman and Handayani, 2017). Dijelaskan bahwa Expert System merupakan bagian dari Artificial Intelegence yang memiliki kemampuan dalam menganalisa permasalahan yang ada dengan konse pembentukan basis pengetahuan dari para ahli yang akan ditelusuri dengan pelacakan sehingga menghasilkan goal yang dicari dalam (Yanto, Werdiningsih and Purwanti, 2017).

Disebutkan juga ES adalah cabang dari AI yang dapat menggunakan knowledge secara luas untuk menyelesaikan permasalahan dengan kualitas yang setara pakar dalam(Yeni et al., 2017), selain itu Expert System merupakan mesin yang dipergunakan dalam memutuskan atau menghasilkan kesimpulan dari hasil pelacakan terhadap kasus-kasus yang ditelusuri pada(Ashari, 2016). Dikemukakan bahwa ES adalah sistem yang dapat melakukan sesuatu dengan kemampuan ahli pada(Masya, Prastiawan and Mubaroq, 2016). Disebutkan bahwa Sistem Pakar ialah layanan konsultasi yang dapat digunakan oleh masyarakat luas pada umumnya dalam (Ramadhan and U. Fatimah, 2018).

Sistem Pakar telah teruji dalam menghadapi atau menyelesaikan permasalahan yang ada seperti menggunakan Sistem Pakar dalam melakukan pendeteksian penyakit Pterigium dengan konsep Viola Jones Algoritm terdapat pada(Hanifah et al., 2018), selain itu juga dijelaskan bahwa Sistem Pakar diterapkan dalam aplikasi layanan konsultasi mendiagnosis Dermatic Imun dalam(Ramadhan, 2018c), kemudian Sistem Pakar juga digunakan dalam diagnosis Varicella Simplex pada(Ramadhan, 2018b), disamping itu terdapat juga penggunaan Sistem Pakar untuk diagnosis penyakit Inflamasi anak dalam(Ramadhan and Fatimah, 2018). Penerapan Sistem Pakar juga digunakan untuk mencari diagnosis reproduksi cancer(Putri and Saputra, 2018).

Selanjutnya untuk pendeteksian penyakit kucing juga menerapkan konsep Sistem Pakar (Nurajizah and Saputra, 2018), dan diagnosis penyakit gigi dan mulut juga menerapkan teknologi Sistem Pakar yang terdapat pada(Tuslaela and Permadi, 2018), selain menyebutkan Sistem Pakar dapat melakukan pendiagosaan terhadap penyakit Polymyalgia Rheumatic itu dalam(Agha, Jarghon and Naser, 2017), kemudian mengemukakan bahwa Sistem Pakar telah dapat menemukan hasil konsultasi terkait penyakit kanker payudara pada(Joshi and Ashish, 2017), tidak hanya itu penerapan Sistem Pakar juga digunakan mengidentifikasi pasien yang terkena demam berdarah dalam(Wulandari, Kadek and Made, 2018), kemudian digunakannya Sistem Pakar dalam mendiagnosis penyakit TBC(Hossain et al., 2017) dan disebutkan bahwa Sistem Pakar telah mampu melakukan diagnosis terhadap penyakit angkel pada kaki didalam (Qwaider and Naser, 2017), kemudian diagnosis terhadap hewan juga pernah diterapkan dengan menggunakan Sistem Pakar seperti digunakan untuk mendiagnosis penyakit pada ayam dalam(Mohamad Hadi, Misdram and A, 2016).

Penerapan Sistem Pakar tidak hanya digunakan dalam dunia medis saja, melainkan telah banyak digunakan dalam bidang-bidang lain, seperti digunakannya Sistem Pakar untuk melakukan pengidentifikasian terhadap kerusakan jaringan LAN (Suyatno and Khairina, 2018), kerusakan perangkat CISCO(Widjaja and Susilo, 2017), dan kerusakan notebook (Jamal and Sukadi, 2015) serta Sistem Pakar juga dapat diterapkan dalam mendeteksi kerusakan Handphone dalam(Sinaga, Hasugian and Manurung, 2018). Kemudian pengidentifikasian kerusakan perangkat sistem elektronik (Wang et al., 2015) dan Sistem Pakar juga digunakan untuk mendiagnosis penyakit jambu biji(Verawaty , Mesran, Suginam, 2017) serta diagnosis terhadap tanaman coklat(Siti Hawa, Abdullah, 2015), selain itu Sistem Pakar juga digunakan dalam mengidentifikasi ikan yang terkontaminasi dengan 
formalin(Hadini, 2017). Dijelaskan bahwa penggunaan Sistem Pakar dalam menganalisa pola wajah dengan teknik biometric (Zuhaer and Alhabib, 2018).

Sistem Pakar yang akan dibangun nantinya akan menerapkan konsep analisa Euclidean Probabiity yang digunakan untuk mencari nilai probabilitas atau kemungkinan dari penyakit yang diderita oleh pasien dengan memandang nilai gejalagejala yang dialami oleh pasien tersebut, hal ini bertujuan untuk mengetahui presentase penyakit yang diderita oleh pasien. Konsep tersebut akan diterapkan ke dalam sebuah sistem berbasis komputer sehingga akan menghasilkan sebuah aplikasi layanan diagnosis untuk mendeteksi penyakit Atopik Dermatis.

Pada penelitian sebelumnya mengemukakan bahwa Euclidean Probability merupakan sebuah metode yang digunakan untuk melakukan perhitungan sehingga dapat menghasilkan nilai kemungkinan dengan teknik pendekatan kasus berdasarkan hal yang terjadi untuk dapat diprediksi sesuatu kemungkinan yang akan muncul (Ramadhan, 2019).

Dengan adanya layanan aplikasi ini diharapakan dapat membantu masyarakat dalam menindaklanjuti permasalahan dalam diagnosis Atopik Dermatis sehingga nantinya dapat dilakukan penanganan dini terhadap pasien yang teridentifikasi Atopik Dermatis, selain itu sistem layanan ini juga akan memberikan pengetahuan dan informasi yang berkaitan dengan Atopik Dermatis sehingga dapat digunakan oleh para petugas kesehatan dan medis dalam mengambil referensi atau bahan pendukung dalam melakukan diagnosis terhadap pasien yang mengalami Atopik Dermatis.

\section{METODE PENELITIAN}

Penelitian ini mengadopsi konsep Research and Development yang berfungsi untuk menghasilkan suatu produk layanan berupa sistem aplikasi yang nantinya dapat dipergunakan dalam mengidentifikasi keluhan masyarakat tentang diagnosis penyakit Atopik Dermatis berdasarkan gejala-gejala klinis yang dialami dengan menerapkan metode Euclidean Probability, selain konsep tersebut terdapat juga kerangka kerja penelitan yang berisi langkah-langkah kerja atau tahapan yang dilakukan untuk mencapai tujuan dari penelitian yang dilakukan. Kerangka kerja tersebut meliputi : pengumpulan knowledge base, penerapan Euclidean Probability, dan implementasi sistem.

Dari kerangka kerja yang yang telah digambarkan, maka dapat dijelaskan sebagai berikut :

a. Pengumpulan Knowledge Base

Tahapan yang dilakukan untuk memperoleh data-data atau informasi yang berkaitan dengan penyakit Atopik Dermatis berdasarkan data kepakaran yang telah terisi data gejala-gejala serta nilai probabilitas penyakit terhadap suatu gejala yang ada.

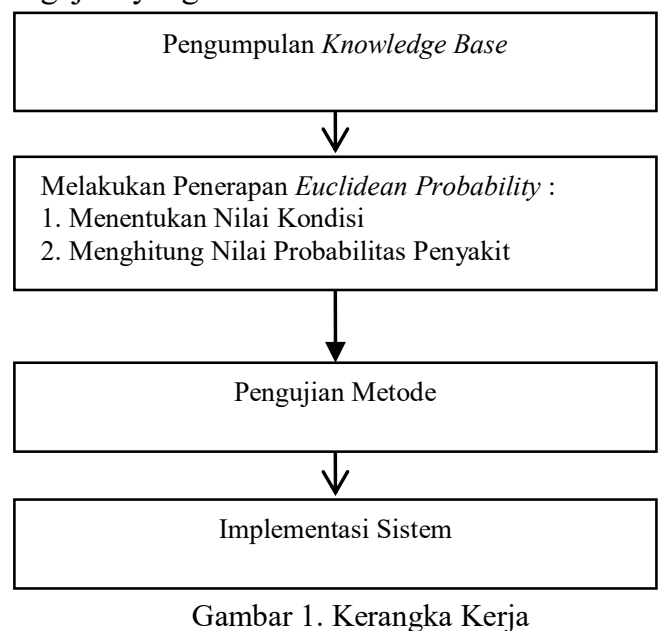

b. Melakukan Penerapan Euclidean Probability

Pada tahapan ini akan dilakukan proses perhitungan dengan menggunakan Euclidean Probability, sehingga nantinya dapat menghasilkan nilai kesimpulan diagnosis pasien berdasarkan gejala yang dialami. Berikut fungsi persamaan (1) dari Euclidean Probability

$$
E P=\sqrt{\left(E_{1} * N B E_{1}\right)^{2}+\ldots+\left(E_{n} * N B E_{n}\right)^{2}}
$$

c. Pengujian Metode

pengujian ini dilakukan untuk mengetahui kelayakan Euclidean Probability dalam melakukan diagnosis terhadap penyakit Atopik Dermatis dengan menggunakan teknik akurasi dan perbandingan dengan metode lainnya.

d. Implementasi Sistem

Setelah konsep Euclidean Probability telah diterapkan dalam sistem, maka proses selanjutnya adalah mengimplementasikan sistem yang telah dibuat untuk dapat melakukan diagnosis terhadap penyakit Atopik Dermatis

\section{HASIL DAN PEMBAHASAN}

Pada pembahasan ini akan dipaparkan tentang cara kerja atau langkah-langkah yang akan dilakukan untuk menghasilkan Sistem Pakar yang mampu melakukan diagnosis terhadap Atopik Dermatis berdasarkan kerangka kerja yang telah disusun.

\subsection{Pengumpulan Knowledge Base}

Untuk membangun sebuah sistem aplikasi cerdas yang mampu dijadikan sebagai layanan konsultasi, maka perlu membentuk basis pengetahuan dengan cara mengumpulkan informasiinformasi atau pengetahuan pakar yang mengerti atau mengetahui tentang penyakit Atopik Dermatis, sehingga dapat menghasilkan solusi diagnosis yang tepat untuk menyelesaikan permasalahan diagnosis 
Atopik Dermatis, pada basis pengetahuan yang akan dibentuk terdiri dari daftar gejela-gejala klinis yang sering dihadapi oleh pasien penderita Atopik Dermatis serta nilai bobot kepastian atau probabilitas dari gejala tersebut yang diperoleh dari pakar kesehatan anak yaitu Dr. Rudidjas, Sp.A(K). Berikut bentuk knowledge base yang telah dikumpulkan.

\begin{tabular}{cclc}
\multicolumn{4}{c}{ Tabel 1. Bentuk Knowledge Base } \\
\hline No & $\begin{array}{c}\text { Kode } \\
\text { Gejala }\end{array}$ & \multicolumn{1}{c}{ Daftar Gejala } & $\begin{array}{c}\text { Nilai } \\
\text { Bobot }\end{array}$ \\
\hline 1 & G01 & Rhinitis & 0,6 \\
\hline 2 & G02 & Rasa gatal & 0,4 \\
\hline 3 & G03 & Kulit bersisik & 0,2 \\
\hline 4 & G04 & Bagian kulit pecah-pecah & 0,4 \\
\hline 5 & G05 & Demam & 0,2 \\
\hline 6 & G06 & Panas pada bagian kulit & 0,6 \\
\hline 7 & G07 & Peradangan kulit & 0,4 \\
\hline
\end{tabular}

Selain data pengetahuan, terdapat pula data persentase kepastian diagnosis yang disajikan sebagai berikut :

Tabel 2. Persentase Diagnosis

\begin{tabular}{cc}
\hline Persentase & Kesimpulan Diagnosis \\
\hline $0-59 \%$ & Negatif(Tidak Pasti) \\
\hline $60 \%-80 \%$ & Mungkin \\
\hline $81 \%-100 \%$ & Sangat Yakin / Pasti \\
\hline
\end{tabular}

Setelah dilakukan pembentukan basis pengetahuan, maka selanjutnya akan dilakukan penerapan metode Euclidean Probability sehingga nantinya dapat menghasilkan sebuah solusi yang sesuai dengan konsep pengetahuan yang telah dibentuk.

\subsection{Penerapan Euclidean Probability}

Pada tahapan ini akan dilakukan proses perhitungan dengan menerapkan Euclidean Probability yang nantinya akan menghasilkan nilai kemungkinan dari kasus yang teleh ditelusuri gejelagejala yang terjadi pada pasien, berikut contoh kasus dari penerapan Euclidean Probability. Diketahui seorang anak mengalami gejala sebagai berikut.

\begin{tabular}{clc}
\multicolumn{3}{c}{ Tabel 3. Data Kasus } \\
\hline No & \multicolumn{1}{c}{ Gejala Yang Dialami } & $\begin{array}{c}\text { Nilai } \\
\text { Bobot }\end{array}$ \\
\hline 1 & Rhinitis (G01) & 0,6 \\
\hline 2 & Demam (G05) & 0,4 \\
\hline 3 & Panas pada bagian kulit (G06) & 0,6 \\
\hline 4 & Peradangan kulit (G07) & 0,4 \\
\hline
\end{tabular}

Setelah diketahui gejala-gejala klinis yang dialami pada kasus yang telah dikemukakan, maka proses selanjutnya adalah melakukan langkahlangkah penerapan konsep Euclidean Probability yang digunakan untuk menghasilkan nilai probabilitas dari gejala yang ada pada kasus di atas.
Berikut langkah-langkah penyelesaian kasus tersebut dengan penerapan Euclidean Probability :

1. Menentukan nilai Kondisi

Nilai kondisi diperoleh dari gejala-gejala yang dialami, jika terdapat gejala yang diderita pasien ada pada basis pengetahuan maka bernilai 1 dan jika tidak ada gejala pada pasien di basis pengetahuan maka bernilai 0(Ramadhan, 2018a).

\begin{tabular}{ccc}
\multicolumn{3}{c}{ Tabel 4. Nilai Kondisi } \\
\hline No & Keterangan Kondisi & Nilai \\
\hline 1 & Ya & 1 \\
\hline 2 & Tidak & 0 \\
\hline
\end{tabular}

2. Menghitung Nilai Probabilitas

Dari nilai kondisi serta daftar gejala yang dialami oleh pasien, maka selanjutnya dilakukan pembentukan fungsi persamaan (2)

$$
\text { Atopik_Dermatis }=\sqrt{\begin{array}{l}
(1 * 0.6)^{2}+(0 * 0.4)^{2}+(0 * 0.2)^{2} \\
+(0 * 0.4)^{2}+(1 * 0.2)^{2}+
\end{array}}=0.96
$$

Berdasarkan perhitungan yang telah dilakukan, maka dapat disimpulkan bahwa pasien tersebut menderita penyakit Atopik Dermatis dengan nilai probabilitas 0,96 atau persentase $96 \%$ dengan keterangan diagnosis Sangat yakin/pasti.

\subsection{Pengujian Metode}

Pada tahapan ini akan dilakukan pengujian metode agar dapat mengetahui metode Euclidean Probability layak atau tidak digunakan dalam melakukan analisa diagnosis terhadap penyakit Atopik Dermatis. Pengujian dilakukan dengan 2 cara yaitu pengujian akurasi dan pengujian dengan perbandingan metode lainnya.

1. Pengujian Akurasi

Dalam pengujian ini akan dilakukan pengambilan dataset berupa sampel riwayat diagnosis yang diperoleh dari Dr. Rudidjas, Sp.A(K) dalam menangani kasus Atopik Dermatis. Berikut ini pengujian akurasi terhadap metode Euclidean Probability:

\begin{tabular}{clccc}
\multicolumn{5}{c}{ Tabel 5. Pengujian Akurasi } \\
\hline \multirow{2}{*}{ No } & $\begin{array}{l}\text { Gejala Yang } \\
\text { Dialami }\end{array}$ & \multicolumn{2}{c}{ Hasil Diagnosis } & $\begin{array}{c}\text { Akurasi } \\
\text { Kecocokan }\end{array}$ \\
\cline { 2 - 4 } 1 & $\begin{array}{l}\text { Demam, kulit } \\
\text { bersisik }\end{array}$ & Negatif & 0.3 (Negatif) & Ya (1) \\
\hline \multirow{2}{*}{2} & $\begin{array}{l}\text { Rhitis, } \\
\text { peradangan } \\
\text { kulit, kulit } \\
\text { pecah-pecah }\end{array}$ & Positif & $\begin{array}{c}\text { (Sangat } \\
\text { Pasti) }\end{array}$ & Ya (1) \\
\hline 3 & $\begin{array}{l}\text { Kulit pecah- } \\
\text { pecah, gatal }\end{array}$ & Positif & $\begin{array}{c}0.6 \\
\text { (Mungkin) }\end{array}$ & Ya (1) \\
\hline & $\begin{array}{l}\text { Panas pada } \\
\text { bagian kulit, } \\
\text { kulit pecah- } \\
\text { pecah, } \\
\text { peradangan } \\
\text { kulit }\end{array}$ & Positif & $\begin{array}{c}\text { (Sangat } \\
\text { Pasti) }\end{array}$ & Ya (1) \\
\hline
\end{tabular}


Setelah melakukan perbandingan hasil diagnosis pakar dengan Euclidean Probability dalam mendiagnosis penyakit Atopik Dermatis menggunakan 4 sampel data kasus, maka dapat diperoleh hasil akurasi dari Euclidean Probability sebagai berikut :

$$
\begin{aligned}
\text { Accuracy } & =\left(\sum \text { appro } / \sum \text { Data }\right) \times 100 \% \\
& =(4 / 4) \times 100 \% \\
& =100 \%
\end{aligned}
$$

Berdasarkan hasil perhitungan akurasi, maka dapat disimpulkan bahwa Euclidean Probability telah teruji dan seusai dengan data pakar dalam melakukan diagnosis Atopik Dermatis dengan nilai akurasi $100 \%$.

2. Perbandingan Metode

Pada pengujian metode ini akan dilakukan perbandingan nilai diagnosis yang dihasilkan oleh Euclidean Probability dengan metode sistem pakar lainnya seperti Teorema Bayes. Berikut hasil diagnosis yang dihasilkan oleh kedua metode tersebut dengan data kasus yang diacak.

\begin{tabular}{cccc}
\multicolumn{4}{c}{ Tabel 6. Perbandingan Metode } \\
\hline \multirow{2}{*}{ No } & $\begin{array}{c}\text { Gejala Yang } \\
\text { Dialami }\end{array}$ & \multicolumn{2}{c}{ Nilai Diagnosis } \\
\cline { 3 - 4 } & \multicolumn{1}{c}{ G01, G02, G03 } & 0.51 & 0.74 \\
\hline 2 & G06, G07 & 0.53 & 0.72 \\
\hline 3 & G05, G04, G02 & 0.37 & 0.60 \\
\hline 4 & G07, G04 & 0.40 & 0.56 \\
\hline
\end{tabular}

Dari data yang telah dikemukakan, maka dapat terlihat bahwa Euclidean Probability memiliki nilai probabilitas diagnosis yang lebih tinggi dibandingkan dengan Teorema Bayes. Dengan hasil perbandingan ini dapat disimpulkan bahwa Euclidean Probability terbukti lebih baik dibanding dengan Teorema Bayes.

Selain itu Euclidean Probability diketahui lebih baik dibanding Forward Chaining, hal ini dikarenakan hasil diagnosis Euclidean Probability memiliki nilai probabilitas atau persentase diagnosis sedangkan Forward Chaining tidak memiliki nilai diagnosis sehingga bisa saja akan terjadi hasil ganda pada kondisi yang terdapat dua hipotesa atau lebih, sehingga Euclidean Probability lebih optimal daripada Forward Chaining.

3. Hasil Pengujian

Berdasarkan hasil pengujian metode yang telah dilakukan, maka dapat diperoleh hasil, bahwa Euclidean Probability telah teruji dalam melakukan diagnosis terhadap penyakit Atopik Dermatis dengan tingkat akurasi $100 \%$ pada sampel data pakar, selain itu juga Euclidean Probability telah terbukti memiliki nilai yang lebih optimal dibandingkan metode yang ada pada Sistem Pakar seperti Teorema Bayes dan Forward Chaining, dengan hasil ini maka dapat dinyatakan bahwa Euclidean Probability telah layak digunakan dalam melakukan diagnosis Atopik Dermatis.

\subsection{Implementasi Sistem}

Dalam fase pengimplementasian sistem yang dilakukan merupakan bentuk pengujian sistem yang telah terbentuk menjadi sebuah layanan aplikasi dekstop programing dengan menggunakan tools Microsoft Visual 2008 sebagai perangkat dalam merancang dan pengkodean yang diterapkan dalam komputer dan Mysql untuk pembentukan database. Sehingga aplikasi ini dapat digunakan untuk mendiagnosis penyakit Atopik Dermatis dengan menggunakan Euclidean Probability, dalam implementasi sistem ini akan ditampilkan bentuk dari tampilan layanan yang disediakan meliputi tampilahn halaman awal sistem aplikasi, tampilan identitias diri pasien, serta layanan konsultasi. Berikut penjelasan dari pengujian dan pengimplementasian sistem aplikasi layanan diagnosis Atopik Dermatis dengan menggunakan Euclidean Probability.

1. Tampilan Halaman Awal

Berikut tampilan dari halaman awal sistem layanan aplikasi diagnosis Atopik Dermatis dengan menggunakan Euclidean Probability yang telah dibangun.

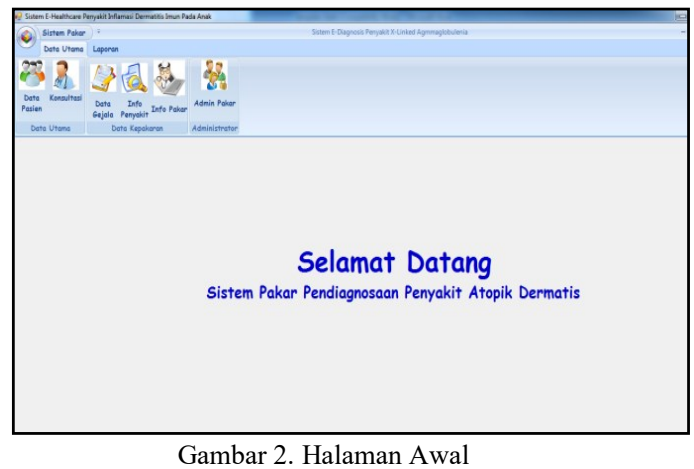

Halaman ini berisi beberapa layanan menu yang dapat digunakan pengguna untuk mengetahui seputar pengetahuan tentang diagnosis Atopik Dermatis, yang meliputi menu identitas pasien, data diagnosis, data pengelolahan pengetahun serta informasi tentang penyakit Atopik Dermatis

2. Tampilan Data Pasien

Halaman ini berisi tentang identitas diri pasien yang nantinya akan menggunakan layanan menu yang terdapat pada aplikasi tersebut, salh satunya adalah menggunakan layanan konsultasi diagnosis Atopik Dermatis, hal inibertujuan untuk menampung hasil diagnosis setiap pasien, sehingga dapat diketahui riwayat gejala maupun penyakit setiap pasien untuk dapat dilakukan penanggulangan atau penanganan terhadap 
pasien tersebut. Pada form tersebut juga disediakan fasilitas pengubahan, penghapusan dan penyimpanan data pasien jika terdapat perubahan data yang terjadi. Berikut adalah tampilan dari identitas diri pasien.

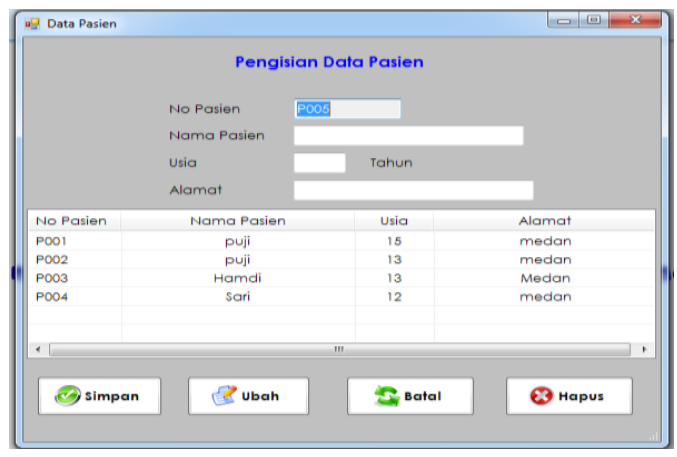

Gambar 3. Halaman Data Pasien

3. Tampilan Diagnosis

Halaman ini berisi daftar gejala-gejala dari penyakit Atopik Dermatis beserta nilai probabilitasnya masing-masing. Halaman dapat dipergunakan oleh pengunjung untuk melakukan konsultasi secara langsung dengan sistem yang telah diadopsi dengan pengetahuan berasal dari pakar, dengan adanya halaman ini dapat mempermudah masyarakat dalam mengetahui tingkat kepastian dari penyakit yang diderita berdasarkan gejala-gejala yang dialami. Berikut adalah tampilan dari layanan diagnosis .

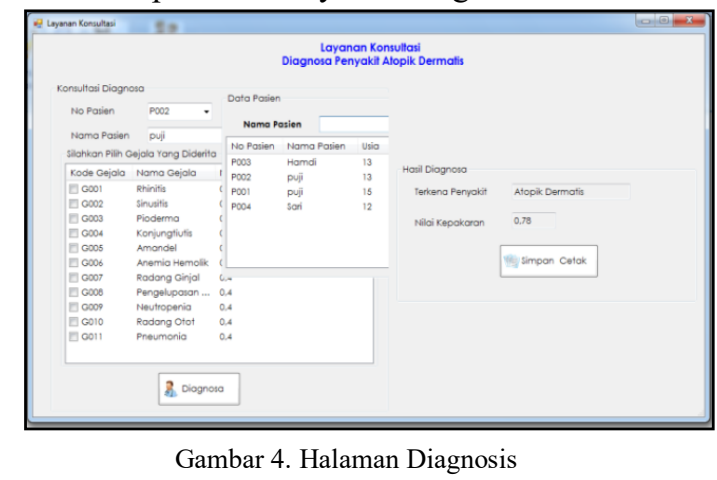

Nantinya pasien akan dapat melihat hasil diagnosis penyakit yang diderita beserta nilai kepastian dari penyakit tersebut dan dapat mencetak hasil diagnosis serta akan tersimpan langsung dalam pendataan rekap medis pasien.

Dari hasil implementasi sistem yang dilakukan, maka dapat diketahui bahwa layanan diagnosis telah berhasil melakukan penerapan metode Euclidean Probability dalam melakukan diagnosis terhadap penyakit Atopik Dermatis dan telah sesuai hasil yang diperoleh sistem dengan hasil dari perhitungan metode.

\section{KESIMPULAN}

Berdasarkan hasil penelitian yang telah dilakukan tentang penerapan metode Euclidean
Probability, maka dapat diperoleh kesimpulan bahwa :

1. Metode Euclidean Probability telah teruji dan berhasil melakukan analisis diagnosis terhadap Atopik Dermatis dengan hasil akurasi 100\% dan telah berhasil membangun aplikasi layanan diagnosa yang menghasilkan kesimpulan dan nilai diagnosis yang telah sesuai dengan perhitungan dan penerapan metode Euclidean Probability.

2. Selain itu dengan dilakukannya penelitian ini dapat diketahui bahwa metode Euclidean Probability menghasilkan nilai diagnosis yang lebih optimal terhadap penyakit yang diderita oleh pasien dibandingan dengan beberapa metode yang ada seperti Bayes dan Forward Chaining sekaligus memberikan pembaharuan konsep perhitungan dalam Sistem Pakar untuk melakukan diagnosis terhadap suatu kejadian.

\section{DAFTAR PUSTAKA}

AGHA, M. EL, JARGHON, A. AND NASER, S. S. A. 2017. Polymyalgia Rheumatic Expert System. August.

AKIB, A. ROMA, J. DAN K. N. 2015. Penyakit Defisiensi Imun. 1st Ed. Jakarta: Ikatan Dokter Indonesia.

ASHARI. 2016. Penerapan Sistem Pakar Untuk Mendiagnosis Penyakit Pecernaan Dengan Pengobatan Alami. November, Pp. 1-9.

HADINI, F. M. 2017. Detection System Milkfish Formalin Android-Based Method Based On Image Eye Using Naive Bayes Classifier. Vol 9(1), Pp. 2-5.

HANIFAH, U. ET AL. 2018. Deteksi Penyakit Pterigium Menggunakan Forward Chaining Dan Algoritma Viola Jones Detection Of Pterigium Disease Using Forward Chaining And Viola. Vol. 5(3), Pp. 6118-6125.

HOSSAIN, M. S. Et Al. 2017. A Belief Rule Based Expert System To Assess Tuberculosis Under Uncertainty. Journal of Medical Systems. Journal Of Medical Systems, 41(3). Doi: 10.1007/S10916-017-0685-8.

JAMAL, A. AND SUKADI. 2015. Rancang Bangun Sistem Pakar Diagnosis Kerusakan Notebook Pada Widodo Computer Ngadirojo Kabupaten Pacitan. Journal Speed - Sentra Penelitian Engineering Dan Edukasi . Vol. 7(3), Pp. 5258.

JOSHI, A. AND ASHISH, M. 2017. Analysis Of KNearest Neighbor Technique For Breast Cancer Disease Classification. International Journal Of Recent Scientific Research. Vol. 8(8), Pp. 1005-19008. Doi: 10.24327/IJRSR.

MAHARANI, A. 2015. Penyakit Kulit. 1st Ed. Edited By Mona. Yogyakarta: Pustaka Baru Press. 
MASYA, F., PRASTIAWAN, H. AND MUBAROQ, S. 2016. Application Design To Diagnosis Of Bone Fracture ( Traditional ) Using Forward Chaining Methods. International Research Journal Of Computer Science (IRJCS), 3(09), Pp. 23-30.

MINARN, WARMAN, I. AND HANDAYANI, W. 2017. Case-Based Reasoning (Cbr) Pada Sistem Pakar Identifikasi Hama Dan Penyakit Tanaman Singkong Dalam Usaha Meningkatkan Produktivitas Tanaman Pangan. Jurnal TEKNOIF. 5(1), Pp. 41-47. Doi: 10.21063/JTIF.2017.V5.1.41-47.

MOHAMAD HADI, MISDRAM, M. AND A, R. F. 2016. Perancangan Sistem Pakar Diagnosis Penyakit Ayam Dengan Metode Forward Chaining. Jimp, 2(No Bagian Volume), Pp. 111-139.

Doi: 10.1017/CBO9781107415324.004.

NURAJIZAH, S. AND SAPUTRA, M. 2018. Sistem Pakar Berbasis Android Untuk Diagnosis Penyakit Kulit Kucing Dengan Metode Forward Chaining. Jurnal Pilar Nusa Mandiri, 14(1), Pp. 7-14. Available At: Http://Ejournal.Nusamandiri.Ac.Id/Ejurnal/Ind ex.Php/Pilar/Article/View/750/Pdf.

PUTRI, S. A. AND SAPUTRA, E. P. 2018. Perancangan Aplikasi Sistem Pakar Diagnosis Awal Kanker Reproduksi Wanita Dengan Metode Certainty Factor. 2(3), Pp. 63-68.

QWAIDER, S. AND NASER, S. S. A. 2017. Expert System For Diagnosing Ankle Diseases: (August).

RAMADHAN, P. S. 2018a. Mengenal Metode Sistem Pakar. 1st Ed. Edited By Fungky. Medan: Penerbit Uwais.

RAMADHAN, P. S. 2018b. Sistem Pakar Pendeteksian Varicella Simplex Dengan Menggunakan Teorema Bayes. 5(5), Pp. 454459.

RAMADHAN, P. S. 2018c. Sistem Pakar Pendiagnosaan Dermatitis Imun Menggunakan Teorema Bayes," Infotekjar.bJurnal Nasional Informatika Dan Teknologi Jaringan. 3(73), Pp. 43-48.

RAMADHAN, P. S. 2019. Penerapan Euclidean Probability Dalam Pendeteksian Penyakit Impetigo. 4(1), Pp. 11-16.

RAMADHAN, P. S. AND FATIMAH. 2018. Sistem E-Healthcare Untuk Mendiagnosis Penyakit Inflamasi Dermatitis Imun Anak Dengan Menggunakan Metode Certainty Factor. 1(1), Pp. 251-256.

RAMADHAN, P. S. AND FATIMAH, U. 2018. Analisis Perbandingan Metode ( Certainty Factor, Dempster Shafer Dan Teorema Bayes ) Untuk Mendiagnosis Penyakit Inflamasi Dermatitis Imun Pada Anak. Saintikom, 17(2),
Pp. 151-157.

SINAGA, B., HASUGIAN, P. M. AND MANURUNG, A. M. 2018. Sistem Pakar Mendiagnosis Kerusakansmartphone. 3(1).

SITI HAWA, Abdullah, U. (2015. Sistem Pakar Diagnosis Penyakit Pada Tanaman Kakao Menggunakan Metode Forward Chaining (Studi Kasus Dinas Perkebunan Indragiri Hilir) .4, Pp. 1-8.

SUYATNO, A. AND KHAIRINA, D. M. 2018. Pendeteksi Gangguan Jaringan Lokal Menggunakan Metode Certainty Factor. 13(2), Pp. 60-64.

TUSLAELA AND PERMADI, D. 2018. Sistem Pakar Diagnosis Penyakit Gigi Dan Mulut Berbasis Web Dengan Metode Forward Chaining,. Jurnal PROSISKO, 5(1), Pp. 17-26. Available At: Http:/EJurnal.Lppmunsera.Org/Index.Php/PROSISKO /Article/View/586/594.

VERAWATY, MESRAN, SUGINAM, A. K. 2017. Jambu Biji Menggunakan Metode Bayes, 2(1), Pp. 78-81.

WANG, T. Et Al. 2015. Fault Diagnosis Of Electric Power Systems Based On Fuzzy Reasoning Spiking Neural P Systems. IEEE Transactions On Power Systems, 30(3), Pp. 1182-1194. Doi: 10.1109/TPWRS.2004.836256.

WIDJAJA, A. AND SUSILO, A. B. 2017. Expert System To Identify Damage Cisco As5300 Device With The Method Of Forward Chaining-Based Client. 9, Pp. 787-805.

WULANDARI, KADEK And MADE, S. 2018. Prediction Of Days In Hospital Dengue Fever Patients Using K-Nearest Neighbor, 3(1), Pp. 23-25.

YANTO, B. F., WERDININGSIH, I. And PURWANTI, E. 2017. Aplikasi Sistem Pakar Diagnosis Penyakit Pada Anak Bawah Lima Tahun Menggunakan Metode Forward Chaining. Journal Of Information Systems Engineering And Business Intelligence, 3(1), Pp. 61-67.

YENI Et Al. 2017. Sistem Pakar Untuk Mendiagnosis Penyakit Tumor Otak Menggunakan Metode Certainty Factor (CF). Jurnal INFOTEK, 2(1), Pp. 0-4. Available At: Http://Ejurnal.Amikstiekomsu.Ac.Id/Index.Php /Infotek/Article/View/98.

ZUHAER, M. And ALHABIB, M. H. M. 2018. Face Recognition System Based On Kernel Discriminant Analysis, K-Nearest Neighbor And Support Vector Machine, 5(3), Pp. 335338. 
Halaman ini sengaja dikosongkan 